\title{
The Contribution of Pattern Making Knowledge and Sewing Skill to the Outcome of Women's Blazer Making
}

\author{
Irmayanti \\ Home Economics Department, Engineering Faculty \\ Universitas Negeri Makassar \\ Makassar, Indonesia \\ irmayanti@unm.ac.id
}

\author{
Syamsul Hadi \\ Mechanical Engineering Department, Engineering Faculty \\ Universitas Negeri Malang \\ Malang, Indonesia
}

\begin{abstract}
The objective of this study is to understand the direct contribution of basic pattern making knowledge, drafting and sewing skill to the outcome of women's blazer making. The results showed that (1) knowledge of pattern making directly and significantly contributed to the outcome of women's blazer making; (2) sewing skill directly and significantly contributed to the outcome of women's blazer making; dan (3) knowledge of pattern making and drafting as well as sewing skill simultaneously contributed to the outcome of women's blazer making.
\end{abstract}

Keywords - knowledge of pattern making and drafting, sewing skill, women's blazer

\section{INTRODUCTION}

Vocational education is one of several government's efforts to produce skilled human resources and experts in a particular field. Fashion Program in the Department of Home Economics, Faculty of Engineering, Universitas Negeri Makassar (PKK FT UNM) is one of the programs that supports these government's efforts in preparing skilled experts in creating and producing arts/products that may benefit the community. It also prepares future educators who are ready to apply their knowledge in the education sector.

The effort of achieving competencies in the Fashion Program PKK FT UNM is similar to other expertises; it requires knowledge (cognitive), attitude (affective), and skill (psychomotor). However, for fashion competencies, training and developing psychomotor abilities are more emphasized than in other expertises. One of the skill courses in Fashion Program PKK FT UNM that strives to provide apparel making knowledge and skills to students is Tailoring.

Tailoring is one of the compulsory and advanced skill courses in the Fashion Program. Through this course, students are expected to know, understand, and implement tailoring techniques in making women's blazer (jas wanita). According to Nusi [1], 'jas' can be translated as blazer, colbert, coat, jacket and jaquette. For women, blazer as a top is usually paired with skirts or pants. Students are anticipated to acquire these competencies following the completion of the Tailoring course: (1) indentifying and describing the theory of tailoring; (2) making blazer pattern based on a particular design/model; (3) experimenting with various cutting techniques and sewing a good quality blazer.

Making a blazer with tailoring techniques needs precision and accuracy and therefore students need to be proficient, precise and patient in the learning processes. The outcome of women's blazer making in the Tailoring course is obtained from the assessment, with certain criteria, of the finished products made by students. Product assessment is an assessment of both the skill in product making and the quality of the resulting product. It is not only assessed from the final product but also from the process of making it. The outcome of women's blazer making in Tailoring course is related to the assessment of students' performance in pattern making, sewing, fitting, finising and the total look of the product, as well as the speed and punctuality in finishing the task.

However, problems often occured during the learning activities of this course. Based on the initial observation, it was found that the expected competencies were not be fully achieved since the resulting products were still lacking in quality and most of the students could not complete their task on time. Being skilled means rapid implementation, in the sense that the completion of the task can be achieved in minimum time. The faster the execution of a task, without sacrificing the expected finished result (quality), the more skilled the student is. Hence, student's skill is an ability that should be measured and assessed of its development.

The reality in the Tailoring course contradicts the goals of vocational education that aim to prepare the students to be skillful and ready to participate in industrial and education sector. Asri in Setiarini [2], posited that the practical lesson of fashion is one of the activities that improves students' potentials and skills. It leads them to be skillful in clothing technologies, ready to be trained, tenacious, handy, independent and ready to work in the field they are in.

Most of the problems occured during this course were caused by the difficulties experienced by the students in pattern making and sewing the blazer. Commonly, the students experienced difficulties in drafting the pattern, making pockets and lapels, and sewing the collars and sleeves. As a result, the lecturer needed to provide an extension of time and extra guidance so that the students 
might be able to finish the task. These problems negatively impacted the students. They became less competent in making a blazer for this course and would be more hesitant and not confident in making women's blazer for the second time. Consequently, it could be said that the students did not have the competencies for making women's blazer and therefore, they were not ready for working in the field. Marniati [3] explained that the competencies of clothing expertise are very necessary and influential in the work readiness. In addition, Lahti argued that understanding various sewing techniques are vital for gaining future opportunities in the clothing industry [4]. Allsop et al [5] stated that "in the UK there is a general assumption that the fashion students will have the basic skills and knowledge gained from the previous study or experience, on which to develop the skills and further technical skills that will ensure graduates are suitably prepared for a career in the fashion and clothing industry."

Slameto [6] maintained that an effective learning process can help students improve their expected abilities according to the instructional goals they wish to achieve. But, in reality, what occured in the learning process of the Tailoring course was the learning process did not run effectively because the students had not been able to fully achieve the expected competencies.

From this argument, it can be concluded that the learning process of blazer making in the Tailoring course needs to be carried out effectively in order to heighten the students' ability in making clothings. In other words, the effectiveness of learning is related to the success of students in achieving learning objectives materialized in increased knowledge and skills.

According to Sagala [7] learning process is not always effective and the outcome of teaching and learning processes is not always ideal because there are a number of obstacles. Problems that students had during the learning process of making a woman's blazer in the Tailoring course are the examples of ineffective learning activities. Therefore, it is highly necessary and important to examine and find helpful solutions to accomplish an effective learning process for making women's blazer in the Tailoring course so that the problems do not persist. If the problems described above continue to occur in the learning process, they will impact the quality of the graduates of Fashion Program of the State University of Makassar.

In addition to having different characteristics, students in the Tailoring course had different educational backgrounds. Not all students in the Fashion Program graduated from vocational high school majoring in Fashion Design; some of them were from public high and Islamic school. Therefore, not all of them had similar experiences and skills in making women's blazer with tailoring techniques.

Purwanto [8] contended that learning is a unique and complex process. Its uniqueness is due to the outcome of learning only occurs in individuals and not in others and each individual displays different learning behavior. A learning process should be able to manage these various characteristics possessed by students because each student performs learning process that differs in terms of knowledge, technologies or attitudes.

When associated with the learning outcome of the Tailoring course, students must be able to manage and develop the aspect of knowledge and technology. Therefore, the basic knowledge of pattern making techniques and sewing skill are crucial preparations in order to achieve maximum learning outcomes.

Pattern making is the first step in clothing. Therefore, the pattern determines the quality of the clothing. Pattern, related to tailoring and sewing, is a piece(s) of cloth or paper used as an example to make a clothing when the fabrics are cut [9]. The pattern construction is made based on the measurements of several parts of the body, calculated systematically and the projected face, back, arms, collars and so forth are then copied on the paper. Datta asserted [10] "pattern making is the art of designing patterns by making templates from which clothing items can be sewn. A pattern making process actually helps to come out with the imagination of designer from the sketching till real product. Flat pattern making for the design of the bodice for torso; skirt for the waist to ankle; pants for the bifurcated body waist to ankle; and sleeve for the arm from shoulder to wrist, as foundations for developing a diverse range of designs and stylistic variations" [11]. The competence of pattern making knowledge may help students apply the techniques of making the correct and accurate pattern of a woman's blazer.

In addition to knowledge and understanding of pattern making, students must also have skills in sewing. Sewing is a very important process in a fashion business. The purpose of sewing is to form a seam connection by combining pieces of cloths that meet the economical production process standard. Sewing skill is the ability of a person to sew a clothing that is based on the pattern(s), uses proper techniques, fits the original design and fabric, and fulfills the certain clothing making standards. The applied sewing techniques are customized to the design and clothing itself. In addition to good patterns, precise sizes, and excellent designs, proper sewing techniques can affect the quality of clothing products. All of these constitute a clothing-making process. If one of the processes is not perfectly carried out, then the product will be less qualified.

Based on the above explanation, it is deemed necessary to examine the characteristics of students as a learning individual concerning possessed knowledge and skills, which in this case is related to the students' knowledge in the design-fitting, blazer pattern making and students' skills in applying sewing techniques in the making of woman's blazer.

It is concluded that knowledge and skills are highly needed by the students. Yet, the reality showed that the Tailoring course is not effective, neither in the students' learning processes, standards of procedures, nor in the time management. Therefore, it is necessary to investigate the contribution of knowledge of pattern making and drafting and sewing skill to the outcome of women's blazer making in the Tailoring course in the Fashion Program of the State University of Makassar.

\section{METHOD}

\section{A. Research Design}

This study aimed to identify the contribution of pattern making knowledge and sewing skills in women's blazer making in the Tailoring course of the Fashion Program PKK 
FT UNM. Based on this objective, the design for this study is correlational ex-post facto with quantitative approach.

\section{B. Sample Size and Sampling Technique}

The population in this study was 111 students of Fashion Program PKK FT UNM who studied in the Tailoring course. The sample in this study was determined by using Proportionate Stratified Random Sampling, taking 50\% of the total population and therefore the sample was 55 people.

\section{Instruments}

The data for knowledge of pattern making and drafting (variable $\mathrm{X}_{1}$ ) was obtained using the students' average score in the Pattern Making and Drafting course. Sewing skill $\left(\mathrm{X}_{2}\right)$ is the level of students' ability in sewing. The data for sewing skill was obtained using the students' average score in the Clothing Technology course. The outcome of women's blazer making (Y) was the attained competence by students in producing women's blazer which was assessed based on the following criteria: (1) preparation, (2) sewing process, (3) sewing outcome, (4) working attitudes and time management.

Instrument used in this study was documentation. Documentation was used to collect the data of student's knowledge of pattern making and drafting $\left(\mathrm{X}_{1}\right)$, sewing skills $\left(\mathrm{X}_{2}\right)$ and the outcome of woman's blazer making $(\mathrm{Y})$ from students' final scores.

\section{Data Analysis}

The analytical techniques used in this study were descriptive and inferential statistical analysis. Analytical technique was used to describe the mean value of each variable. The path analysis was then used to measure the contribution indicated by the path coefficient of each path diagram of the causal relationship between variables $\mathrm{X} 1$ and $\mathrm{X} 2$ on Y. Correlation and regression analysis were the basis for the calculation of path coefficients.

\section{RESUlt AND DiscusSiON}

A) Research Result

The mean value of each variable is shown in Figure 1. The findings indicate that the level of students' understanding/knowledge of pattern making and drafting, sewing skill and the outcome of womens' blazer making is in good category. The classical assumption test was performed. The result showed that the research data was normally distributed and had a linear relationship. Hypothesis testing' results are described below:

TABLE I. RESULT OF HYPOTHESIS TESTING OF THE CONTRIBUTION OF KNOWLEDGE OF PATTERN MAKING AND DRAFTING (X1) AND SEWING SKILL (X2) TO WOMEN'S BLAZER MAKING (Y)

\begin{tabular}{|c|l|l|r|}
\hline \multirow{2}{*}{ Hypothesis } & \multicolumn{3}{|c|}{ Correlation } \\
\cline { 2 - 4 } & \multicolumn{1}{|c|}{ Sig } & \multicolumn{1}{c|}{ Condition } & Result \\
\hline X1 towards Y & 0.046 & Sig $<0.05$ & Significant \\
\hline X2 towards Y & 0.005 & Sig $<0.05$ & Significant \\
\hline
\end{tabular}

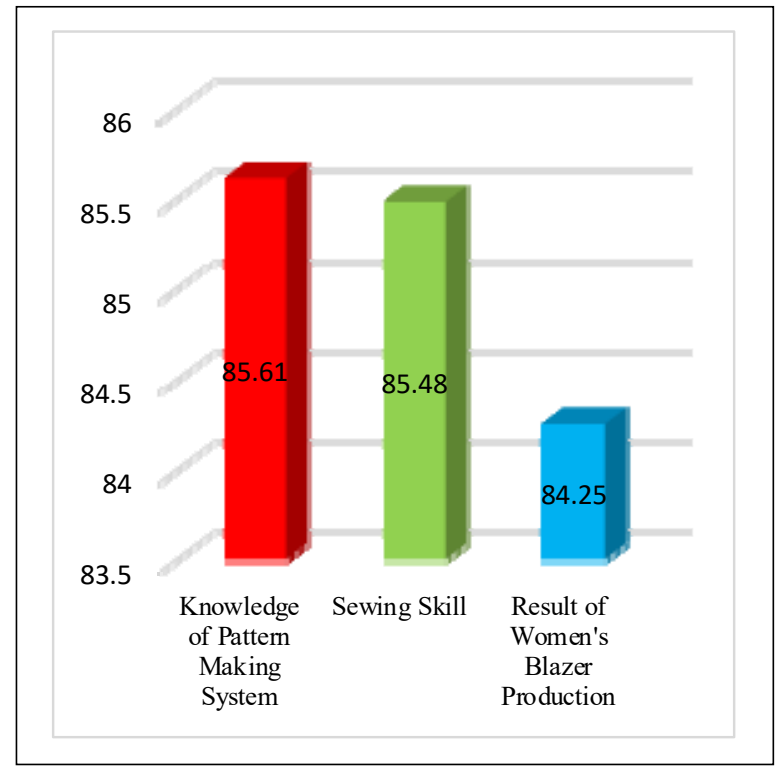

Fig. 1. The students' average score for each variable

TABLE II. RESULT OF REGRESSION TESTING OF THE CONTRIBUTION OF KNOWLEDGE OF PATTERN MAKING AND DRAFTING (X1) AND SEWING SKILL (X2) TO WOMEN'S BLAZER MAKING (Y)

\begin{tabular}{|c|l|l|l|l|l|l|}
\hline \multicolumn{2}{|c|}{ Model } & $\begin{array}{c}\text { Sum of } \\
\text { Squares }\end{array}$ & Df & Mean Square & F & Sig. \\
\hline \multirow{3}{*}{1} & Regression & 635.452 & 2 & 317.726 & 19.198 & $.000 \mathrm{a}$ \\
\cline { 2 - 8 } & Residual & 860.586 & 52 & 16.550 & & \\
\cline { 2 - 8 } & Total & 1496.039 & 54 & & & \\
\hline
\end{tabular}

TABLE III. SUMMARY OF REGRESSION TESTING OF THE CONTRIBUTION OF KNOWLEDGE OF PATTERN MAKING AND DRAFTING (X1) AND SEWING SKILL (X2) TO WOMEN'S BLAZER MAKING (Y)

\begin{tabular}{|l|l|l|l|l|}
\hline Model & R & R Square & Adjusted R Square & $\begin{array}{c}\text { Std. Error of the } \\
\text { Estimate }\end{array}$ \\
\hline 1 & $.652^{\mathrm{a}}$ & .425 & .403 & 4.068 \\
\hline
\end{tabular}

TABLE IV. COEFFICIENTS OF THE REGRESSION TESTING OF THE CONTRIBUTION OF KNOWLEDGE OF PATTERN MAKING AND DRAFTING (X1) AND SEWING SKILL (X2) TO WOMEN'S BLAZER MAKING (Y)

\begin{tabular}{|c|c|c|c|c|c|c|}
\hline \multirow{2}{*}{\multicolumn{2}{|c|}{ Model }} & \multicolumn{2}{|c|}{$\begin{array}{l}\text { Unstandardized } \\
\text { Coefficients }\end{array}$} & $\begin{array}{c}\text { Standardized } \\
\text { Coefficients }\end{array}$ & \multirow[t]{2}{*}{$\mathbf{t}$} & \multirow[t]{2}{*}{ Sig. } \\
\hline & & B & Std. Error & Beta & & \\
\hline & (Constant) & 25.368 & 9.584 & & 2.647 & .011 \\
\hline 1 & $\begin{array}{l}\text { Knowledge of } \\
\text { Pattern } \\
\text { Making and } \\
\text { Drafting }\end{array}$ & .273 & .146 & .276 & 1.875 & .066 \\
\hline & Sewing skill & .416 & .143 & 428 & 2.912 & .005 \\
\hline
\end{tabular}


The basis of the overall analysis result shown in Table II is: if the probability value 0.05 is greater than or equal to the probability value of sig or $0.05 \geq \operatorname{sig}$, then the next test (individual testing) can be performed. Also, Table II shows the $\mathrm{F}$ value of 19.198 with probability value (sig) of 0.000 . The obtained sig value is $<0,05$, therefore the individual test can be completed. The equation structure is

$\mathrm{Y}=0.276 \mathrm{X} 1+0.428 \mathrm{X} 2+0.75 \varepsilon 1$

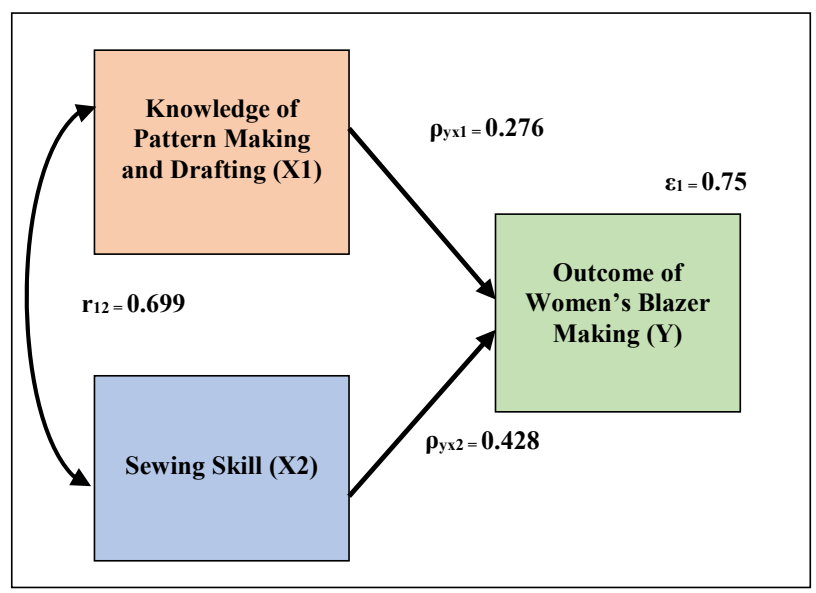

Fig. 2. Path Diagram of $\mathrm{X} 1$ and $\mathrm{X} 2$ towards $\mathrm{Y}$

TABle V. Path CoEfFicient of KNOWledge of PATtern MaKing AND DRAFTING (X1) AND SEWING SKILL (X2) TO WOMEN'S BLAZER MAKING (Y)

\begin{tabular}{|l|l|l|l|l|}
\hline $\begin{array}{c}\text { Variables } \\
\text { Contribution }\end{array}$ & $\begin{array}{c}\text { Path } \\
\text { Coefficient }\end{array}$ & $\begin{array}{c}\text { Direct } \\
\text { Contributi } \\
\text { on }\end{array}$ & $\begin{array}{c}\text { Simultaneo } \\
\text { us } \\
\text { Contributi } \\
\text { on }\end{array}$ & $\begin{array}{c}\text { Total } \\
\text { Contributi } \\
\text { on }\end{array}$ \\
\hline $\mathrm{X} 1$ & 0.276 & 0.276 & - & $7.6 \%$ \\
\hline $\mathrm{X} 2$ & 0.428 & 0.428 & - & $18.3 \%$ \\
\hline$\varepsilon_{1}$ & 0.75 & $\begin{array}{l}1-0.425= \\
0.575\end{array}$ & - & - \\
\hline $\mathrm{X} 1$ dan $\mathrm{X} 2$ & - & - & 0.425 & $42.5 \%$ \\
\hline
\end{tabular}

A) The Contribution of Knowledge of Pattern Making and Drafting to The Outcome of Women's Blazer Making in the Tailoring Course

Based on the results of data analysis, there was a significant contribution of students' knowledge of pattern making and drafting to the outcome of women's blazer making of the Tailoring course. The results showed that there was a positive and significant correlation between students' knowledge in pattern making and drafting to the outcome of women's blazer-making. This means that the better the knowledge and understanding of the students in making and drafting patterns, the more the quality of the women's blazer outcome. The variable of pattern making and drafting knowledge can explain the $7.6 \%$ higher result of the blazer outcome.

This result is supported by the study by Surya (2004) who stated that basic knowledge is one of the requirements in starting any activity for meeting all needs and goals. Basic knowledge is highly necessary in supporting an effective learning activity. Besides, Varmayanti [12] also found that there was a correlation between the ability to make pattern for women's wear and the outcome of drafted pattern of women's work suit.

In line with previous studies, Budiningsih also found that there was a significant contribution of students' initial knowledge towards students' learning outcome. Furthermore, Budiningsih [13] specified that there was a correlation between students' characteristics (cognitive style) and students' learning outcome and interest.

In addition, the results of this study are in accordance with the theory by Wancik [14] who defined drafted pattern as a basic pattern which is drawn according to its line, cut out and separated following its respective lines and shapes. In other words, the basic skills in pattern making and drafting are the guidelines that one must understand to be able to make patterns and develop all types of clothing designs, especially women's attire in the Tailoring course.

Therefore, the knowledge from Pattern Making and Drafting course should be improved. According to Marzano (as cited by Defila) [15], knowledge is an important factor in thought processes; without enough information of a subject, other working systems will work less efficiently and a successful learning activities will not be achieved.

B) The Contribution of Sewing Skill to the Outcome of Women's Blazer Making in the Tailoring Course

Another result of this study is that the sewing skill significantly contributes towards the blazer outcome. There was a significant correlation between sewing skill and the outcome of the product. The correlation coefficient was $0.621 \quad(\operatorname{sig}<0.05)$, showing that there was a strong correlation between these two variables. This means that the more skillful a student is, the better the quality of the blazer will be. The sewing skill explained the higher women's blazer quality by $18.3 \%$.

This finding is confirmed by the study by Yanti who found that learning skill influenced the learning outcome in students majoring in cooperative economics education. Similarly, Yuliastuti [16] found that skills influenced nurses' performances.

Furthermore, based on Ernawati's concept [17], it can be concluded that in addition to good pattern, proper sewing techniques will influence the quality of the clothing outcome (product). These are a cycle in the process of producing a clothing; if one stage is wrong, then the quality of the final product will be negatively affected. It was also stated by Breward [18] that "preshaped dress involves cutting and sewing lengths of cloth to make a garment fit the body." In other words, sewing skills are very essentials in the process of clothing production, especially in making a woman's blazer in the Tailoring course. Tenacity and attentiveness during clothing production process will result in a beautiful outfit.

It can be concluded from the findings in this study that sewing skill significantly contributes to the outcome of women's blazer in the Tailoring course. Therefore, it is to be understood that students' sewing skill plays an important role to the outcome of women's blazer making in the Tailoring course. 
Sewing skills are indispensable for students studying clothing and fashion design. Thus, to implement the proper sewing techniques that are consistent with design, technical skills in basic, hem, parts-of-clothing, and lapel sewing are highly important and necessary, particularly for the Tailoring course.

C) The Simultaneous Contribution of knowledge of Pattern Making and Drafting and Sewing Skill to the Outcome of Women's Blazer Making in the Tailoring Course

Based on the result of simultaneous data analysis, it was confirmed that the knowledge of pattern making and drafting and sewing skill are correlated with the outcome of women's blazer making. Correlation coeffient of 0.699 demonstrated a strong, positive influence on the women's blazer making in the Tailoring course.

The third finding of this study concluded that the knowledge of pattern making and drafting, as well as sewing skill simultaneously contributed to the $42.5 \%$ higher level of outcome of women's blazer making and the rest $57.5 \%$ was influenced by other factors.

As science and technology grow, so does the fashion field. The development of fashion design should be followed by the development in pattern making and sewing techniques.

\section{CONCLUSION}

Students' knowledge and understanding in basic pattern making and drafting contribute significantly to the outcome of women's blazer making in the Tailoring course. In other words, the more the students understand the basics of pattern making and drafting the better the outcome quality will be. Students' skill in sewing significantly contributes $(18.3 \%)$ to the outcome of women's blazer making in the Tailoring course. Thus, it can be concluded that the more skillful the students are the better the quality of the blazer will be. The basic knowledge of pattern making and drafting and sewing skill simultaneously contribute to the $42.5 \%$ higher level of outcome of the women's blazer making in the Tailoring course and the rest $57.5 \%$ is influenced by other factors.

\section{ACKNOWLEDGEMENT}

Highest appreciation for all material and moral assistance to: (1) Rector of Universitas Negeri Makassar, (2)
Head of Home Economic Department, Faculty of Engineering Universitas Negeri Makassar, (3) Instructors of the training for helping in the implementation of this research, and (4) Students of Home Economic Department as subjects in this research.

\section{REFERENCES}

[1] A. Nusi, Sonny \& Zaman, Jas Wanita: Sejarah-Gaya \& Cara Praktis Pembuatan Jas Wanita. Jakarta: Meutia Cipta Sarana., 2002.

[2] Y. F. Setiarini, "Pembelajaran Praktikum Pada Program Keahlian Busana di SMK Daerah Istimewa Yogyakarta," Cakrawala Pendidik., no. c, 2004.

[3] Marniati and S C Wibawa, "The Impact of Fashion Competence and Achievement Motivation Toward College Student 's Working Readiness on 'Cipta Karya ' subject," in IOP Conference Series: Materials Science and Engineering, 2018.

[4] H. Lahti, "Learning sewing techniques through an inquiry," vol. 45, pp. 178-188, 2012

[5] T. Allsop, Debbie and Cassidy, "University of Huddersfield Repository," Glob. Fash. Manag. Conf., 2017.

[6] Slameto, Belajar dan Faktor-Faktor yang Mempengaruhi. Jakarta: Rineka Cipta, 2010.

[7] S. Sagala, Konsep dan Makna Pembelajaran. Bandung: Penerbit Alfabeta, 2012.

[8] Purwanto, Evaluasi Hasil Belajar. Yogyakarta: Pustaka Pelajar, 2011.

[9] P. Muliawan, Konstruksi Pola Busana Wanita. Jakarta: PT. BPK Gunung Mulia, 1990.

[10] Datta DB \& Partha Seal, "Various Approaches in Pattern Making for Garment Sector," J. Text. Eng. Fash. Technol., vol. 4, no. 1, pp. 4-9, 2018.

[11] C. M. D. Schmidt, "Second Skin : Annette Kellerman , The Modern Swimsuit, and an Australian Contribution to Global Fashion," 2008.

[12] A. Varmayanti, "Hubungan Kemampuan Analisis Desain, Mengukur Tubuh Dan Membuat Pola Dasar Dengan Hasil Pecah Pola Busana Kerja Wanita Di SMK Negeri 6 Surabaya,” J. Tata Busana, 2013.

[13] C. A. Budiningsih, "Karakteristik Siswa sebagai Pijakan dalam Penelitian Pembelajaran,” Cakrawala Pendidik., pp. 160-173, 2011.

[14] M. H. Wancik, Bina Busana. Jakarta: PT. Gramedia Pustaka Utama, 2013.

[15] Defila, Ranah Pengetahuan Menurut Bloom, Cangelosi dan Marzano. 2012.

[16] Yuliastuti IIng, "Pengaruh Pengetahuan, Keterampilan dan Sikap terhadap Kinerja Perawat dalam Penatalaksanaan Kasus Flu Burung di RSUP. H. Adam Malik," 2008.

[17] W. N. Ernawati, Izwerni, "Tata Busana," in Tata Busana, Jilid I., Winarti, Ed. Indonesia: Direktorat Pembinaan Sekolah Menengah Kejuruan Direktorat Jenderal Manajemen Pendidikan Dasar dan Menengah Departemen Pendidikan Nasional, 2008, p. 101.

[18] C. Breward, Encyclopedia Of Clothing and Fashion. Frank Menchaca, 2005 . 